\title{
Allerjik Rinite Benzeyen Semptomlara Sahip Hastaların İnhalan Allerjenlere Karşı Gösterdiği Duyarlılıkta Doğum Ayı Önemli Bir Faktör müdür?
}

$\underline{\text { Ahmet Hamdi KEPEKCI }}^{1}$, Cenk KIG $^{2}$

\begin{abstract}
Öz
İstanbul'un Avrupa bölgesinde gerçekleştirilen retrospektif çalışma ile, allerjik rinit (AR) benzeri semptomları olan hastalarda görülen inhalan allerjen duyarlılığı ile kişilerin doğum ayları arasında bir ilişki olup olmadığını araştırmak amaçlanmıştır. AR'ye benzeyen semptomlar gösteren 3460 hastaya deri prik test uygulanmıştır. Çalışmada kullanılan alerjenler kökenlerine göre bitkiler, mantarlar, ev tozu akarları ve hayvan epiteli (kedi ve köpek) olmak üzere 4 ana kategoride gruplandırılmıştır. Sonuçlar inhalan allerjenler bakımından SPSS analiz yazılımı kullanılarak retrospektif olarak değerlendirilmiştir. 2302 hastanın $(\% 66,5)$ yaygın inhalan allerjenlerden en az bir veya daha fazlasına karşı duyarlılık gösterdiği belirlendi. Polen duyarlılığ 1 en yüksek oranda $(\% 53,8)$ görülürken en az rastlanan duyarlılık $(\% 21,7)$ hayvan epiteline karşı elde edildi. Haziran ve Temmuz ayında doğanların toz akarlarına karşı duyarlılık gösterme olasılığının arttığı $(p<0,012)$ buna karşılık, Ağustos ayında doğan bireylerin Quercus Robur'a karşı duyarlı olma olasılıklarının daha düşük olduğu $(\mathrm{p}<0,038)$ bulundu. Yaz dönemlerinde doğan hastaların ev tozu akarlarına (HDM) karşı duyarlılık gösterme olasılığının yüksek olduğu görülmüştür. Ev tozu akarlarına karşı evlerde mücadele edilerek olabildiğince alt seviyede tutmak önemlidir. Bu kapsamda elde ettiğimiz bulgular, AR'ye benzeyen semptomlara sahip hastalar için kişiselleştirilmiş koruyucu sağlık hizmetlerinin planlanmasına katkı sunabilir.
\end{abstract}

Anahtar Kelimeler: Deri prick testi, allerjik rinit, inhalan allerjen, doğum ayı
Yayın Bilgisi

Gönderi Tarihi: 15.10 .2018

Kabul Tarihi: 28.12.2018

Online Yayın Tarihi: 30.09.2019

DOI: $10.26453 /$ otjhs.470839

Sorumlu Yazar

Ahmet Hamdi KEPEKÇI 1: Audiometry, Health Occupation High-School,İstanbul Yeni Yüzyil

University, Istanbul, Turkey.

2: Department of Otolaryngology, Meltem Private Hospital, Istanbul,

Turkey.

Tel: 00905332040462

e-Mail:

ahmethamdi.kepekci@yeniyuzyil.edu.tr

Is Month of Birth an Important Factor for Sensitization to Inhalant Allergens in Patients with Symptoms

\section{Similar to Allergic Rhinitis?}

$\underline{\text { Ahmet Hamdi KEPEKCI }}{ }^{1}, \underline{\text { Cenk KIG }}^{2}$

\begin{abstract}
In this retrospective study, performed in the European region of Istanbul, it was aimed to investigate whether the birth month is a factor in inhalant allergen sensitivity in patients with symptoms similar to allergic rhinitis (AR). Skin prick test was applied to 3460 patients with symptoms similar to AR. The allergens used in the study were grouped according to their origin in four main categories: plants, fungi, house dust mites and animal epithelium (cat and dog). The results were retrospectively evaluated using SPSS analysis software. 2302 patients $(66.5 \%)$ had at least one or more sensitization to the common inhalant allergens. Pollen sensitization was found to be the most common $(53.8 \%)$ while sensitivity to the animal dander was the lowest $(21.7 \%)$ among the individuals. Birth in June and July increased the risk for developing sensitization to the house dust mite $(\mathrm{p}<$ 0.012) whereas, birth in August was correlated with a lower risk of sensitization to Quercus Robur ( $\mathrm{p}<0.038$ ). This study showed that individuals born in summer period can be at risk for developing HDM sensitizations. Thus, it is important to keep the house dust mites as low as possible by taking preventative measures in houses. Our findings may contribute to the planning of personalized preventive health care services for patients with AR-like symptoms.
\end{abstract}

Keywords: Skin prick test, allergic rhinitis, inhalant allergens, birth of month

Article Info

Received: 15.10 .2018

Accepted: 28.12.2018

Online Published: 30.09.2019

DOI: 10.26453/otjhs.470839

Corresponding Author

Ahmet Hamdi KEPEKCI 1: Audiometry, Health Occupation High-School,İstanbul Yeni Yüzyil University, Istanbul, Turkey. 2: Department of Otolaryngology, Meltem Private Hospital, Istanbul,

Turkey.

Tel: 00905332040462

e-Mail:

ahmethamdi.kepekci@yeniyuzyil.edu.tr ${ }^{1}$ Meltem Hospital, Department of Otolaryngology and Yeni Yüzyıl University, Health Occupation High-School Audiometry, Istanbul, Turkey

${ }^{2}$ Yeni Yuzyil University, Faculty of Medicine, Department of Medical Biology and Genetics, İstanbul/TURKEY

\section{INTRODUCTION}

Allergic rhinitis (AR) is frequently affected by environmental factors. ${ }^{1} \mathrm{AR}$ is a heterogeneous disorder with high prevalence and often can remain undiagnosed for a long time. It is characterized by the symptoms which are 
similar to rhinitis such as sneezing, itching, nasal congestion, and rhinorrhea. The rapid onset and offset of the symptoms which are often associated with exposure to inhalant allergens are one of the most important characteristics of seasonal AR. Perennial AR is often more difficult to detect because of the overlapping symptoms of sinusitis, respiratory infections, and vasomotor rhinitis.

According to statistics from the World Health Organization (WHO), hundreds of millions of people in the world have rhinitis and it is estimated that 235 million people have asthma. ${ }^{2}$ AR affects the quality of life and its' high prevalence raises concerns about the community health and socio-economic well-being.

Prevalence of allergic diseases varies depending on the diversity of the environmental allergens and the level of exposure to allergens. In recent years, the prevalence of allergic diseases has increased in both developed and developing countries. In industrialized countries, however, sensitivity to aeroallergens ranges between $25 \%$ to $50 \%$ of the whole population. ${ }^{3,4}$ According to the literature, race, age, and geographical regions may affect the prevalence of $A R$ in the communities and AR poses a health problem to the general public.

Sensitivity to allergens can be associated with a number of environmental factors such as climate, geography, lifestyle, and humidity. These variables are among the most common factors that affect the allergen response of individuals to pollens, HDMs, fungi, and animal dander. ${ }^{5,} 6$ Especially, in big and developing cities allergic reactions are amongst the major concerns. For example, when the rich biodiversity of Istanbul meets with poor hygiene conditions and the increasing number of environmental pollutants, the risk of developing allergic reactions is also expected to rise. Studies suggest that changes in the global climate and air pollution may contribute to the release and production of weed and tree pollens. Similarly, the rising temperatures also increase the growth rate of molds and fungi which are important allergens for people with rhinitis. ${ }^{7}$ Skin prick test (SPT) is a commonly used method for testing allergen reactivity. This test basically includes the appropriate use of specific allergen extracts along with the positive and negative controls. Minimally invasive nature of its' application and relatively short time required for performing the test for multiple types of allergens at once make SPT a popular method. The most common inhalant allergens tested by SPT include animal dander, fungi (molds) dust mites such as dermatophagoides, and pollens.

The present study has been conducted with the data obtained from SPT applied to 3460 patients who visited an ENT clinic due to symptoms similar to AR. The SPT results were investigated for possible correlations in different groups according to the gender and month of 
birth. We have also performed a correlation analysis for the coexistence of sensitizations.

\section{MATERIALS AND METHODS}

\section{Subjects}

We have collected retrospective data of patients who visited an ENT clinic in Istanbul between March 2008 and August 2015 and showed symptoms similar to AR. A total of 3460 patients (ages ranging between 5 months -77 years) who had symptoms similar to AR were included in the study. The diagnosis was made on the basis of the following criteria which are set according to the guidelines of "allergic rhinitis and its impact on asthma" (ARIA): physical examination findings included sneezing, nasal congestion, frequent and transparent watery runny nose, nasal itching and burning in the eyes.

The data used in this study were retrospectively analyzed in accordance with guidelines of the Ethics Committee of "Istanbul Egitim ve Arastirma Hastanesi Klinik Arastirmalar Etik Kurulu” (Approval No. 12.18.2015/746).

\section{Skin Prick Test (SPT)}

Patients with symptoms similar to AR using antihistamine medications, immune suppressive drugs, and antidepressants were excluded in the study. The tests were performed in compliance with the recommended method of prick testing based on the SPT-European standards. ${ }^{8}$ Briefly, these criteria include the appropriate use of specific allergen extracts, positive and negative controls. The interpretation of the test should be made in 15-20 minutes after application where a wheal size of $3 \mathrm{~mm}$ or greater in diameter is defined as a positive result. ${ }^{4,9}$

Allergens used in the study can roughly be grouped into 4 main categories according to their origins: pollens, fungi, house dust mites (HDMs) and animal dander (from cats and dogs). The types and origins of the allergens (Reinback, German Stallergenes S. A., France) were as follows: Tree Pollen Mix, Olive, Poplar, Red Oak, Grass Pollen, Grain Pollen, Weed Pollen, Alternaria Alternate, Aspergillus Fumigatus, Dermatophagoides Farinae, Dermatophagoides Pteronyssinus, Dog and Cat Epithelium (Table 1).

\section{Statistical analysis}

Statistical analysis was performed using SPSS for Windows, Version 21.0 (SPSS Inc., USA). ANOVA and Tukey tests were performed for testing the correlation between the types of allergens and the month of birth. Statistical significance for the correlation between the allergens of fungal and plant origins was evaluated by Pearson correlation. The statistical significance was accepted as $\mathrm{p}<0.05$.

\section{RESULTS}

\section{Allergen sensitization among the patients}

Analysis of the data obtained from SPTs revealed that out of the 3460 individuals with 
symptoms similar to AR, 2302 patients (66.5\%) had at least one or more sensitization to the common inhalant allergens while 1159 individuals of the patients $(33.5 \%)$ showed no sensitization against the allergens tested in this study (Figure 1).

Next, we have checked the sensitization of allergens among the SPT positive patients. Sensitization to the pollens was found to be the most common $(53.8 \%)$ and the sensitization to animal dander was the lowest $(21.7 \%)$ among the individuals tested (Figure 2). Analysis of the SPT results, according to the month of birth revealed that birth in June and July was associated with an increased incidence of sensitization to the dust mite $D$. farina $\mathrm{p}<0.012$ ) and birth in August was associated with a lower risk of sensitization to Quercus Robur when compared to those born in the other months of the year $(\mathrm{p}<0.038)($ Table 1). On the other hand sensitization to Dermatophagoides farina was the least common among the individuals born in February (Table 1).

\section{DISCUSSION}

We demonstrated that more than half of the individuals with AR-like symptoms had at least one sensitization to the common inhalant allergens tested in this study. Because of its' rich flora, these allergens are present throughout the year in Istanbul and this may in part explain the high frequency of sensitizations against allergens of plant origin. ${ }^{10}$ In parallel with this hypothesis, airborne allergens such as pollens and fungal spores have also been suggested as the main cause of allergic respiratory problems in temperate countries. ${ }^{11}$ Interestingly, geographic location and direction of winds may as well play a role in the spreading of certain types of plant originated allergens. Sensitization to pollens was also reported to be the most common allergen in the rural region of Bushehr, Iran. $^{12}$

Animal-borne allergens in the home and workplace are of clinical importance. Allergens of animal origin include hair, dander, urine, and saliva of pets or wild animals. This may be related to the living arrangements and adaptation to life in big cities in which most apartments do not allow for a life together with animals or even pets in some cases. However, some studies suggest that in certain regions of the western society there is higher sensitivity to the cat and dog dander. ${ }^{13}$ This variation can be explained by the fact that owning pets may be a more common practice in certain regions of societies. In accordance with this notion, among the most common aeroallergens, sensitivity to cat and dog litter has an important place in European and North American countries. ${ }^{1,14} \mathrm{We}$ found that animal dander was the least common cause of allergic reactions probably due to feeding a low number of domestic animals in our country (Table 1).

Aspergillus sp. is indoor fungi which are one of the most commonly seen fungal species and 
they can even be isolated from dust mites. There may be more than 250.000 spores of indoor fungi per cubic meter of inhaled air. ${ }^{15}$

In this sense, we investigated the possible link between sensitivity to allergens and season of birth in our test group. In line with previous findings, our analysis of the data grouped according to the birth dates revealed that the month of the birth played a role in sensitivity to allergens. ${ }^{16,17}$ While sensitization to HDM was least common among the individuals born in February (Table 1), birth in June and July was associated with an increased risk for sensitization to the dust mites (Table 1). Favorable changes in temperature and humidity required for the thriving of dust mites appear to coincide with this time period of the year. ${ }^{18}$ Thus, these findings suggest a correlation between the month of birth and the risk of developing sensitization against house dust mites.

House dust allergens showed seasonal changes due to moisture levels, although the symptoms occur perennial. The seasonal pattern of mite sensitivity was shown. ${ }^{19}$ In our study, sensitivity to mold was not affected by the birth month. Our results were consistent with previously reported studies. $^{19-22}$

On the other hand, although some studies have not demonstrated the prevalence of pollen allergen after early exposure ${ }^{23,24}$, there are studies showing that children born in the pollen season between 3rd and 6th months increase the risk of allergy to grass. Children born in the pollen season (between March and September) have shown an increased risk of pollen allergy (especially weed and tree pollen). ${ }^{22}$

On the other hand, individuals born in August had a lower risk of sensitization to Quercus Robur (Table 1). The Quercus pollens were reported to peak during the period from March to May. ${ }^{25}$ The significant decrease in the number of Quercus pollen grains in Istanbul after this period of the year, ${ }^{25}$ may in part explain the reduced risk for having sensitization to Quercus Robur.

In accordance with the previous studies, ${ }^{16,17}$ our findings also strongly suggest the link between the sensitization to certain types of allergens and birth of month $(\mathrm{p}<0.05)$ (Table 1).

This cross-sectional study performed in the European region of Istanbul represents the sensitivity profile of individuals with symptoms similar to AR. Data obtained from this retrospective analysis may be useful for tracking potential changes in the long-term sensitivity profile of patients with symptoms similar to AR. More importantly, we believe that our findings might be used implications for preventive health care services at designing living spaces, improving working conditions and refining environmental quality for sensitized individuals. Every individual in the study may not be born in Istanbul. This situation is the limitation of our study. We believe that these findings may contribute to the assessment of the types of 
common inhalant allergens to be avoided in patients with symptoms similar to $\mathrm{AR}$ and thereby, developing an effective preventative health care plan especially for those residing in the European region of Istanbul.

Conflict of Interest: The authors declare no conflict of interest.

Financial Disclosure: The authors declare that this study received no financial support.

Ethics committee: Protocol of this study was approved by ethics issue. The data were retrospectively analyzed in accordance with guidelines of the Ethics Committee of "Istanbul Egitim ve Arastirma Hastanesi Klinik Arastirmalar Etik Kurulu" (Approval No. 12.18.2015/746).

\section{REFERENCES}

1. Salo PM, Arbes SJ, Jaramillo R, et al. Prevalence of allergic sensitization in the United States: results from the National Health and Nutrition Examination Survey (NHANES) 2005-2006. J Allergy Clin Immunol. 2014;134(2):350-9.

2. WHO. Asthma 2014. Available from: https://www.who.int/en/news-room/factsheets/detail/asthma. Date of access: 20.07.2018

3. Dottorini M, Bruni B, Peccini F, et al. Skin prick-test reactivity to aeroallergens and allergic symptoms in an urban population of central Italy: a longitudinal study. Clinical \& Experimental Allergy. 2007;37(2):18896.

4. Katelaris CH, Lee BW, Potter PC, et al. Prevalence and diversity of allergic rhinitis in regions of the world beyond Europe and North America. Clin Exp Allergy. 2012;42(2):186-207.

5. Yasan H, Aynali G, Akkuş Ö, et al. Alerjik rinitten sorumlu alerjen profilinin değişimi ve semptomlarla korelasyonu. KBB-Forum. 2006.

6. Cingi C, Topuz B, Songu $\mathrm{M}$, et al. Prevalence of allergic rhinitis among the adult population in Turkey. Acta Otolaryngol. 2010;130(5):600-6.

7. Dorner T, Lawrence K, Rieder A, Kunze M. Epidemiology of allergies in Austria. Results of the first Austrian allergy report. Wien Med Wochenschr. 2007;157(11-12):235-42.

8. Heinzerling L, Mari A, Bergmann KC, et al. The skin prick test-European standards. Clinical and translational allergy. 2013;3(1):3.

9. Olivieri M, Verlato G, Corsico A, et al. Prevalence and features of allergic rhinitis in Italy. Allergy. 2002;57(7):600-6.

10. Kepeci AH, Kig C. Analysis of inhalant allergen sensitivity by age groups in 
patients from Istanbul. Biomedical Research. 2018;29(13):2841-5.

11. Kepekci AH, Koker MY. Comparison of allergen sensitization according to age and sex using skin prick test in patients with allergic rhinitis. Fresenius Environmental Bulletin 2018;27(7):5113-8.

12. Farrokhi S, Gheybi MK, Movahed A, et al. Common aeroallergens in patients with asthma and allergic rhinitis living in southwestern part of Iran: based on skin prick test reactivity. Iranian Journal of Allergy, Asthma and Immunology. 2015;14(2):133-138.

13. Zahradnik E, Raulf M. Animal allergens and their presence in the environment. Frontiers in Immunology. 2014;5:76.

14. Bousquet PJ, Chinn S, Janson C, et al. Geographical variation in the prevalence of positive skin tests to environmental aeroallergens in the European Community Respiratory Health Survey I. Allergy. 2007;62(3):301-9.

15. Żukiewicz-Sobczak WA. The role of fungi in allergic diseases. Advances in Dermatology and Allergology/Postępy Dermatologii I Alergologii. 2013;30(1):42-45.

16. Vassallo MF, Banerji A, Rudders SA, et al. Season of birth and food allergy in children. Ann Allergy Asthma Immunol. 2010;104(4):307-13.
17. Ramesh M, Cohen L, Kachirayan M, Rajan T. Relationship of date of birth and seasonal allergies. Journal of Allergy and Clinical Immunology. 2010;125(2):AB32.

18. Arlian LG. Water balance and humidity requirements of house dust mites. Exp Appl Acarol. 1992;16(1-2):15-35.

19. Businco L, Cantani A, Farinella F, Businco E. Month of birth and grass pollen or mite sensitization in children with respiratory allergy: a significant relationship. Clinical Experimental Allergy. 1988;18(3):269-74.

20. Carosso A, Ruffino C, Bugiani M. The effect of birth season on pollenosis. Ann Allergy Asthma Immunol. 1986;56(4):300-3

21. Cronicr S, Kjellman NI. Predictors of atopic disease: cord blood $\operatorname{IgE}$ and month of birth. Allergy. 1986;41(1):6870.

22. Erel F, Karaayvaz M, Caliskaner Z, Ozanguc N. The allergen spectrum in Turkey and the relationships between allergens and age, sex, birth month, birthplace, blood groups and family history of atopy. J Investig Allergol Clin Immunol. 1998;8(4):226-33.

23. Korsgaard J, Dahl R. Sensitivity to house dust mite and grass pollen in adults: influence of the month of birth. 
Clinical Experimental Allergy.

1983;13(6):529-36.

24. Björkstén F, Suoniemi I, Koski V.

Neonatal birch-pollen contact and

subsequent allergy to birch pollen.

Clinical Experimental Allergy.

1980;10(5):585-91.

25. Celenk S, Bicakci A, Tamay Z, et al. Airborne pollen in European and Asian parts of Istanbul. Environ Monit Assess. 2010;164(1-4):391-402. 
Table 1: The percentage of sensitization to allergens in groups made according to the month of birth.

\begin{tabular}{|c|c|c|c|c|c|c|c|c|c|c|c|c|c|c|}
\hline \multirow{2}{*}{ Allergen } & \multirow{2}{*}{ Median range } & \multicolumn{11}{|c|}{ Month of birth } & \multirow[b]{2}{*}{12} & \multirow[b]{2}{*}{$\mathrm{P}^{*}$} \\
\hline & & 1 & 2 & 3 & 4 & 5 & 6 & 7 & 8 & 9 & 10 & 11 & & \\
\hline \multirow{2}{*}{ Trees Mix } & $>$ Median & 155 & 39 & 36 & 30 & 38 & 34 & 43 & 38 & 29 & 39 & 40 & 26 & \multirow{2}{*}{0.257} \\
\hline & $<=$ Median & 680 & 218 & 228 & 213 & 214 & 217 & 187 & 218 & 191 & 192 & 184 & 171 & \\
\hline \multirow{2}{*}{ Olea Europea } & $>$ Median & 96 & 28 & 21 & 26 & 27 & 22 & 22 & 15 & 20 & 22 & 20 & 22 & \multirow{2}{*}{0.506} \\
\hline & $<=$ Median & 739 & 229 & 243 & 217 & 225 & 229 & 208 & 241 & 200 & 209 & 204 & 175 & \\
\hline \multirow{2}{*}{ Populus Nigra } & $>$ Median & 80 & 23 & 16 & 22 & 22 & 17 & 17 & 13 & 16 & 15 & 13 & 11 & \multirow{2}{*}{0.449} \\
\hline & $<=$ Median & 755 & 234 & 248 & 221 & 230 & 234 & 213 & 243 & 204 & 216 & 211 & 186 & \\
\hline \multirow{2}{*}{ Quercus Robur } & $>$ Median & 73 & 16 & 12 & 21 & 25 & 17 & 19 & 9 & 21 & 17 & 20 & 21 & \multirow{2}{*}{$0.038 *$} \\
\hline & $<=$ Median & 762 & 241 & 252 & 222 & 227 & 234 & 211 & 247 & 199 & 214 & 204 & 176 & \\
\hline \multirow{2}{*}{ Pollens IV } & $>$ Median & 127 & 30 & 30 & 23 & 33 & 38 & 37 & 38 & 30 & 29 & 26 & 37 & \multirow{2}{*}{0.159} \\
\hline & $<=$ Median & 708 & 227 & 234 & 220 & 219 & 213 & 193 & 218 & 190 & 202 & 198 & 160 & \\
\hline \multirow{2}{*}{ Polens III } & $>$ Median & 94 & 23 & 29 & 19 & 28 & 24 & 31 & 31 & 19 & 25 & 16 & 22 & \multirow{2}{*}{0.464} \\
\hline & $<=$ Median & 741 & 234 & 235 & 224 & 224 & 227 & 199 & 225 & 201 & 206 & 208 & 175 & \\
\hline \multirow{2}{*}{ Polens V } & > Median & 91 & 29 & 15 & 29 & 32 & 29 & 25 & 20 & 26 & 23 & 22 & 23 & \multirow{2}{*}{0.219} \\
\hline & $<=$ Median & 744 & 228 & 249 & 214 & 220 & 222 & 205 & 236 & 194 & 208 & 202 & 174 & \\
\hline \multirow{2}{*}{$\begin{array}{l}\text { Alternaria } \\
\text { Alternata }\end{array}$} & $>$ Median & 85 & 27 & 25 & 29 & 35 & 24 & 25 & 35 & 35 & 20 & 21 & 22 & \multirow{2}{*}{0.100} \\
\hline & $<=$ Median & 750 & 230 & 239 & 214 & 217 & 227 & 205 & 221 & 185 & 211 & 203 & 175 & \\
\hline \multirow{2}{*}{$\begin{array}{l}\text { Aspergillus } \\
\text { Fumigatus }\end{array}$} & $>$ Median & 99 & 30 & 23 & 32 & 32 & 26 & 30 & 20 & 25 & 29 & 28 & 21 & \multirow{2}{*}{0.522} \\
\hline & $<=$ Median & 736 & 227 & 241 & 211 & 220 & 225 & 200 & 236 & 195 & 202 & 196 & 176 & \\
\hline \multirow{2}{*}{$\begin{array}{l}\text { Dermatophagoides } \\
\text { Farinae }\end{array}$} & $>$ Median & 186 & 42 & 61 & 51 & 52 & 71 & 64 & 51 & 54 & 62 & 44 & 49 & \multirow{2}{*}{$0.012 *$} \\
\hline & $<=$ Median & 649 & 215 & 203 & 192 & 200 & 180 & 166 & 205 & 166 & 169 & 180 & 148 & \\
\hline \multirow{2}{*}{$\begin{array}{l}\text { Dermatophagoides } \\
\text { Pteronyssinus }\end{array}$} & $>$ Median & 164 & 46 & 58 & 47 & 45 & 49 & 54 & 56 & 47 & 42 & 40 & 44 & \multirow{2}{*}{0.718} \\
\hline & $<=$ Median & 671 & 211 & 206 & 196 & 207 & 202 & 176 & 200 & 173 & 189 & 184 & 153 & \\
\hline \multirow{2}{*}{ Dog Epithelium } & $>$ Median & 58 & 16 & 26 & 13 & 21 & 20 & 18 & 14 & 19 & 20 & 17 & 17 & \\
\hline & $<=$ Median & 777 & 241 & 238 & 230 & 231 & 231 & 212 & 242 & 201 & 211 & 207 & 180 & 0.J5 \\
\hline & $>$ Median & 91 & 22 & 34 & 26 & 19 & 31 & 21 & 24 & 20 & 24 & 20 & 20 & \\
\hline & $<=$ Median & 744 & 235 & 230 & 217 & 233 & 220 & 209 & 232 & 200 & 207 & 204 & 177 & \\
\hline
\end{tabular}

*The distribution and statistical significance were analyzed by ANOVA and Tukey tests using SPSS. The significant associations were shown as bold characters $(\mathrm{p}<0.05)$. 


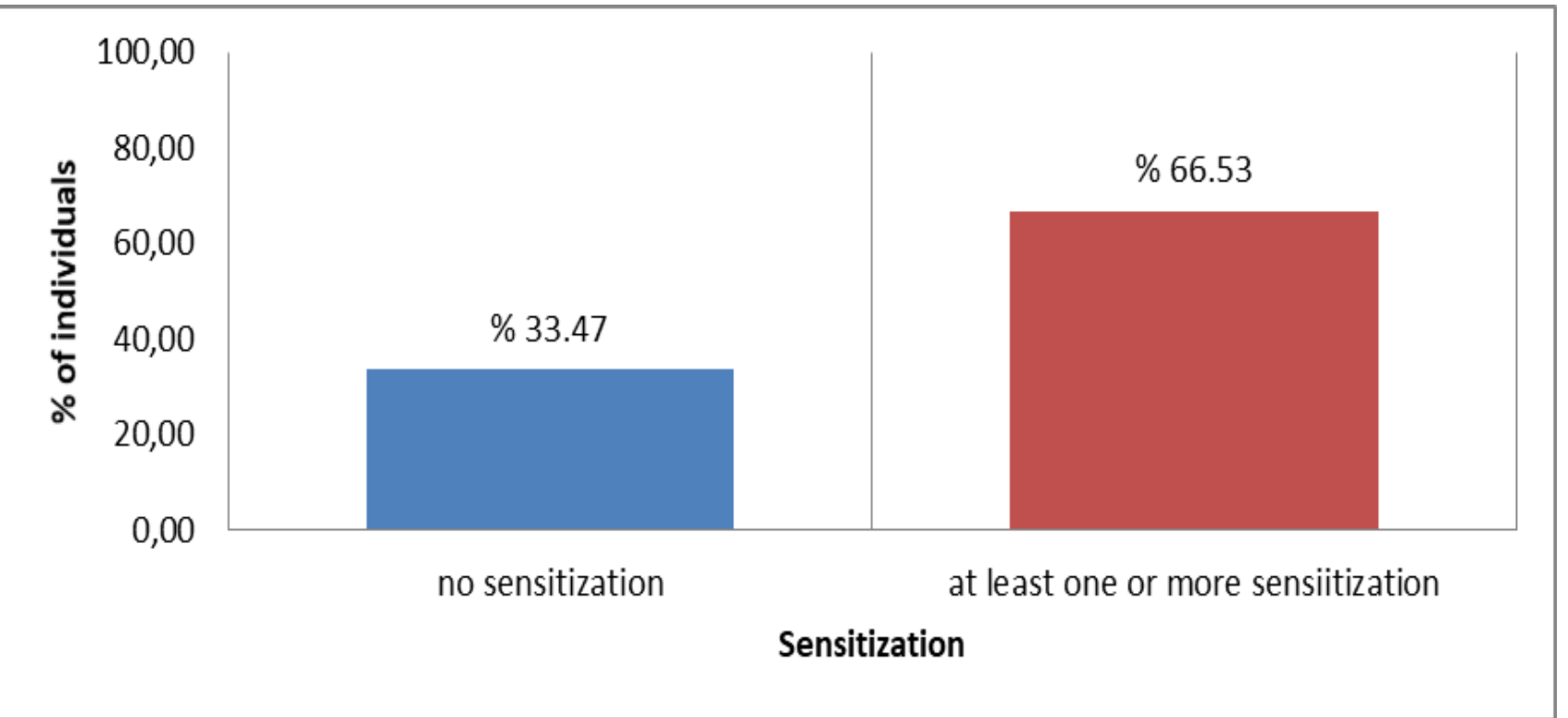

Figure 1. Allergen sensitization among the patients with symptoms similar to AR. A total of 3460 patients with symptoms similar to AR were included. For SPT, a wheal $\geq 3 \mathrm{~mm}$ as compared to that of the negative control in diameter was considered positive. 


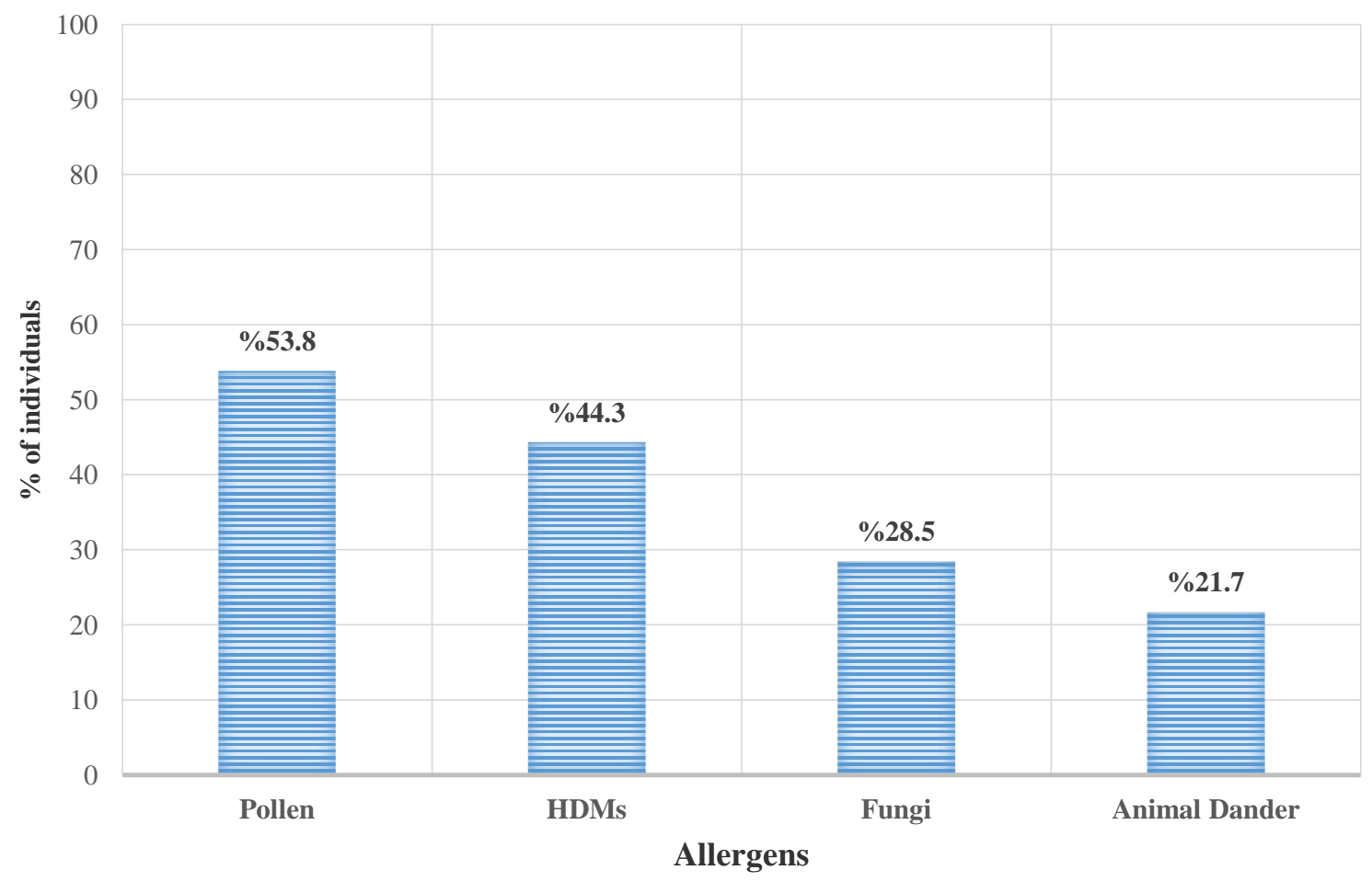

Figure 2: The distribution of allergen sensitization among patients with AR-like symptoms. The distribution of sensitivity to four main categories of allergens among the patients was analyzed using SPSS. 